\title{
Physico-Chemical Properties of Soil, Influenced by Different Levels of NPK, FYM and Sulphur in Mustard-Moong Cropping Sequence
}

\author{
Singh Yeshpal ${ }^{1 *}$, B.S. Duhan ${ }^{2}$ and N.L. Sharma ${ }^{1}$ \\ ${ }^{1}$ Department of Agricultural chemistry and Soil science, Amar Singh P.G. College, Lakhaoti, \\ Bulandshahr-245407 (U.P.), India \\ ${ }^{2}$ Department of Soil Science, CCSHAU, Hisar-125004, Haryana, India \\ *Corresponding author
}

\begin{abstract}
Keywords
Physical and chemical soil properties, Fertility status and nutrient balance.

Article Info

Accepted:

28 October 2017

Available Online:

10 December 2017 $42.45 \%$ to $44.87 \%$, available-N from 147.6 to $224.1 \mathrm{~kg} \mathrm{ha}^{-1}$, available-P from 8.6 to 17.9 $\mathrm{kg} \mathrm{ha}^{-1}$, available-K from 81.0 to $126.9 \mathrm{~kg} \mathrm{ha}^{-1}$ and available-S from 16.2 to $21.8 \mathrm{~kg} \mathrm{ha}^{-1}$ with the application of $100 \%$ RDF of NPK combined with FYM and sulphur. A highest residual available- $\mathrm{N}$ content $225.1 \mathrm{~kg} \mathrm{ha}^{-1}$ with the treatment consisting of $100 \% \mathrm{RDF}$ of NPK combined with FYM, highest residual available-P18.6 kg ha ${ }^{-1}$ was obtained with the application of $100 \%$ recommended dose of NPK alone and residual available-K of soil i.e. $129 \mathrm{~kg} \mathrm{ha}^{-1}$ was recorded with the treatment $100 \%$ RDF of NPK combined with sulphur alone whereas residual available-S $21.8 \mathrm{~kg} \mathrm{ha}^{-1}$ was found highest with treatment consisting $100 \%$ RDF of NPK combined with both FYM and sulphur. A positive balance of available N, P and K and S were recorded in the soil by using with NPK, FYM and sulphur combinations. The highest net gain of NPK i.e. $+34.0,+11.10$ and $+24.0 \mathrm{~kg} \mathrm{ha}^{-1}$ respectively, were recorded from treatment $100 \%$ RDF of NPK in combination with FYM and sulphur whereas, a maximum net gain of sulphur $+5.2 \mathrm{~kg} \mathrm{ha}^{-1}$ was recorded with the application $75 \%$ RDF of NPK in combination with FYM and sulphur both whereas pH, $\mathrm{ECe}$ and bulk density are concerned during this experiment, these parameters were not significantly influenced.
\end{abstract}

\section{A B S T R A C T}

Experimental results revealed that application of both levels 75 and $100 \%$ of recommended dose of NPK in combination with FYM and sulphur both significantly improved the soil properties and residual fertility. The Organic carbon content of soil increased from 2.2 to $3.4 \mathrm{~g} \mathrm{~kg}^{-1}$ soil, water holding capacity (WHC) improved from

\section{Introduction}

Soil is a habitat for plants. As such, the soil's physical, chemical, and biological properties affect plant growth. Soil management practices also greatly affect the soil organic matter and soil fertility. The organic matter levels depend upon factors such as crop rotation, tillage methods, fertility management including use of inorganic fertilizers and organic manures and other components of cropping system (Purakayastha et al., 2008). Continuous cultivation of crops has resulted in reduction in soil organic carbon and soil physical properties in general (Bhattacharya et al., 2007). Fertilizers are usually applied to soil for increasing or maintaining crop yields to meet the increasing demand of food (Haynes and Naidu, 1998). Application of inorganic 
fertilizers results in higher soil organic matter accumulation and biological activity due to increased plant biomass production and organic matter returns to soil in the form of decaying roots, litter and crop residues (Suman et al., 2002). Addition of organic matter enhances soil organic carbon content, which is an important indicator of soil quality and crop productivity (Lal, 2003). Fertilizer applications could affect soil physical properties directly or indirectly such as aggregate stability, water holding capacity, porosity, infiltration rate, hydraulic conductivity and bulk density due to increases in soil organic matter and organic carbon content and also affect the chemical composition of soil solution which can be responsible for dispersion/flocculation of clay particles and thus, affects the soil aggregation stability. Reduction in soil organic matter can degrade soil quality and fertility resulting in reduced agronomic productivity and its lowered the soil bulk density and compaction (Sharma and Subehia, 2003), resulting in increased total porosity and water infiltration rate (Ndiaye et al., 2003).

A traditional agricultural practice of applying nutrients was through organic manures such as green manures, farmyard manure (FYM). Organic manure applications improved soil physical properties through increased soil aggregation (Zhang and Fang, 2015), improved aggregate stability, and decrease in the volume of micro-pores while increasing macro-pores (Hati et al., 2006), Organic manures and compost applications resulted in higher organic content compared to same amount of inorganic fertilizers applications (Gregorich et al., 2001). Although, the accumulation of SOM through applied organic manures depends upon the rate of decomposition process. Several studies have reported that FYM plus inorganic NPK applications in irrigated systems resulted in reduced bulk density, higher soil organic carbon and hydraulic conductivity and improved soil structure and microbial communities (Bhattacharya et al., 2007). Sulphur is equally effective in improving the soil properties and crop yields as well (Chand et al., 1977). Sulphur is takes place in three essential amino acids named cysteine, cystine and methionine, which are essential for protein synthesis and also involved in the formation of chlorophyll, glucosides and glucosinolates and thiamine in the crops.

A judicious combination of organic and inorganic fertilizers is widely recognized strategy of integrated nutrient management to sustain agronomic productivity and improve soil fertility. Fertilizer applications and crop rotation can regulate carbon cycling dynamics and soil carbon storage through its effects on biological activity in soil and the amount and quality of residue returned to the soil. Longterm experiments can be more useful for studying the changes in soil properties and processes over time and for obtaining information on sustainability of agricultural systems for developing future strategies to maintain soil health. Therefore, a two year experiment was planned to study the "Physico-chemical properties of soil, influenced by different levels of NPK, FYM and Sulphur in Mustard-moong Cropping sequence".

\section{Materials and Methods}

A dual year research experiment in Rabi season of 2009-10 and 2011-12 was conducted at Agricultural research farm of Amar Singh (PG) College Lakhaoti, Bulandshahar (U.P). Experimental site is situated at $28^{0} \mathrm{~N}$ Latitude, $77^{0} \mathrm{E}$ Longitude. In general, the climate was subtropical with remarkable humidity. Summers were extremely hot and dry. Month of May and June were hottest with mean maximum temperature ranging between $35^{\circ} \mathrm{C}$ and $45^{\circ} \mathrm{C}$. 
The winters were cold and frosty. The average minimum temperature in the coldest month of January varied from 4.3 to $6.5^{\circ} \mathrm{C}$. The mean annual rainfall was $671 \mathrm{~mm}$ recording about $75 \%$ in monsoon season.

The soil texture of experimental site was sandy loam, having $\mathrm{pH}$ 7.6, E.Ce $0.30 \mathrm{~d} \mathrm{Sm}^{-1}$, OC $2.4 \mathrm{~g} \mathrm{Kg}^{-1}$ soil, BD (Bulk density) $1.36 \mathrm{mg}$ $\mathrm{m}^{3}$, water holding capacity (WHC) $42.10 \%$, available $\mathrm{N}, \mathrm{P}, \mathrm{K}$ and $\mathrm{S}$ were $196 \mathrm{~kg} \mathrm{ha}^{-1}$ (low), $9.0 \mathrm{~kg} \mathrm{ha}^{-1}$ (low), $110 \mathrm{~kg} \mathrm{ha}^{-1}$ (medium) and $16.0 \mathrm{~kg} \mathrm{ha}^{-1}$ (deficient) respectively. The experiments were laid out in a Randomised Block Design RBD and replicated thrice.

In all, there were 9 treatment combinations as per detail of treatments given in Table 1 consisted of two levels of FYM (0 and 5 M.T. $\left.\mathrm{ha}^{-1}\right)$, three levels of NPK $(0 \%, 75 \%$ and $100 \%$ RDF) and two levels of sulphur (0 and $40 \mathrm{~kg} \mathrm{ha}^{-1}$ ). The nutrients $\mathrm{N}, \mathrm{P}, \mathrm{K}$ and $\mathrm{S}$ were applied through Urea, DAP, MOP and elemental sulphur respectively whereas, fully decomposed FYM was added as organic manure. Indian mustard (Brassica juncea L.) was grown as a first test crop followed by moong crop in the same plot to study the residual effect of the treatments in question. The experiments were planted on $27^{\text {th }}$ October-2009, $28^{\text {th }}$ October-2011 and $9^{\text {th }}$ April-2010, $11^{\text {th }}$ April-2012 respectively for mustard and moong crops.

Soil samples were taken with the help of steel tube auger and prepared after air-drying, ground, sieved $(2 \mathrm{~mm})$ and analyzed for $\mathrm{pH}$ by glass electrode $\mathrm{pH}$ meter, ECe (electrical conductivity) by conductivity bridge method, OC (organic carbon) by Walkley and Black's rapid titration method (Jackson), available-N by Alkaline permanganate method (Subbiah and Asija), Available-P by Olsen's method (Olsen), Available-K by Flame photometer (Chopra and Kanwar), Available-Sulphur by Turbidity method (Chesnin and Yien).

\section{Post-harvest physico-chemical properties of soil}

\section{Organic carbon content}

A Conjunctive use of organic and inorganic source of nutrients significantly improved the carbon content of soil shows in Figure 1. Significantly and highest organic carbon content $3.6 \mathrm{~g} \mathrm{~kg}^{-1}$ soil was recorded with the application of $100 \%$ RDF of NPK combined with FYM followed by $3.4 \mathrm{~g} \mathrm{~kg}^{-1}$ soil with the treatment $100 \%$ RDF of NPK in combination with both FYM and sulphur than $3.2 \mathrm{~g} \mathrm{~kg}^{-1}$ soil with $75 \%$ RDF of NPK combined with both FYM and sulphur or combined with FYM alone whereas, least $2.2 \mathrm{~g} \mathrm{~kg}^{-1}$ soil with the control treatment.

Similar findings were reported by Shankar et al., (2002), Miles et al., (2011), Masood et al., (2014) and Brar et al., (2015).

\section{Water holding capacity (WHC \%)}

Significant variations were noted in WHC as influenced by different levels of NPK FYM and sulphur (Fig. 2). Both levels of NPK either alone with FYM or in combination with both FYM and sulphur caused a marked increase in WHC, however, a maximum value $44.87 \%$ of WHC was noted against treatment containing $100 \%$ RDF of NPK combined with FYM and Sulphur followed by $44.68 \%$ with the treatment having $100 \%$ RDF of NPK with FYM as compared to control $(42.45 \%)$.Corroborative findings have also been reported by Tadesse et al., (2013) and Parewa et al., (2014).

\section{Bulk density}

The effects shown in Figure 3, on bulk density the treatments were not found statistically significant during both the years of experimentation. Tadesse et al., (2013) and 
Parewa et al., (2014) also reported the same findings.

\section{pH and ECe}

Some variations in $\mathrm{pH}$ and $\mathrm{ECe}$ of the soil as influenced by treatments, were noted, however, the differences among the treatments as regarded both for $\mathrm{pH}$ and $\mathrm{ECe}$ of the soil were not found significant statistically for both the years of experimentation depicted by Figure 3 and results were same reported by Tadesse et al., (2013) and Hemalata et al., (2013).

Table.1 Detail of the treatments

\begin{tabular}{|c|l|}
\hline Treatments & \multicolumn{1}{c|}{ Description } \\
\hline $\mathrm{T}_{1}$ & Control \\
\hline $\mathrm{T}_{2}$ & $75 \%$ RDF of NPK \\
\hline $\mathrm{T}_{3}$ & $75 \%$ RDF of NPK + FYM \\
\hline $\mathrm{T}_{4}$ & $75 \%$ RDF of NPK + Sulphur \\
\hline $\mathrm{T}_{5}$ & $75 \%$ RDF of NPK + FYM + Sulphur \\
\hline $\mathrm{T}_{6}$ & $100 \%$ RDF of NPK \\
\hline $\mathrm{T}_{7}$ & $100 \%$ RDF of NPK + FYM \\
\hline $\mathrm{T}_{8}$ & $100 \%$ RDF of NPK + Sulphur \\
\hline $\mathrm{T}_{9}$ & $100 \%$ RDF of NPK + FYM + Sulphur \\
\hline
\end{tabular}

Fig.1 Influence of different levels of NPK, FYM and sulphur on soil organic carbon (CD at $5 \% 0.23$ )

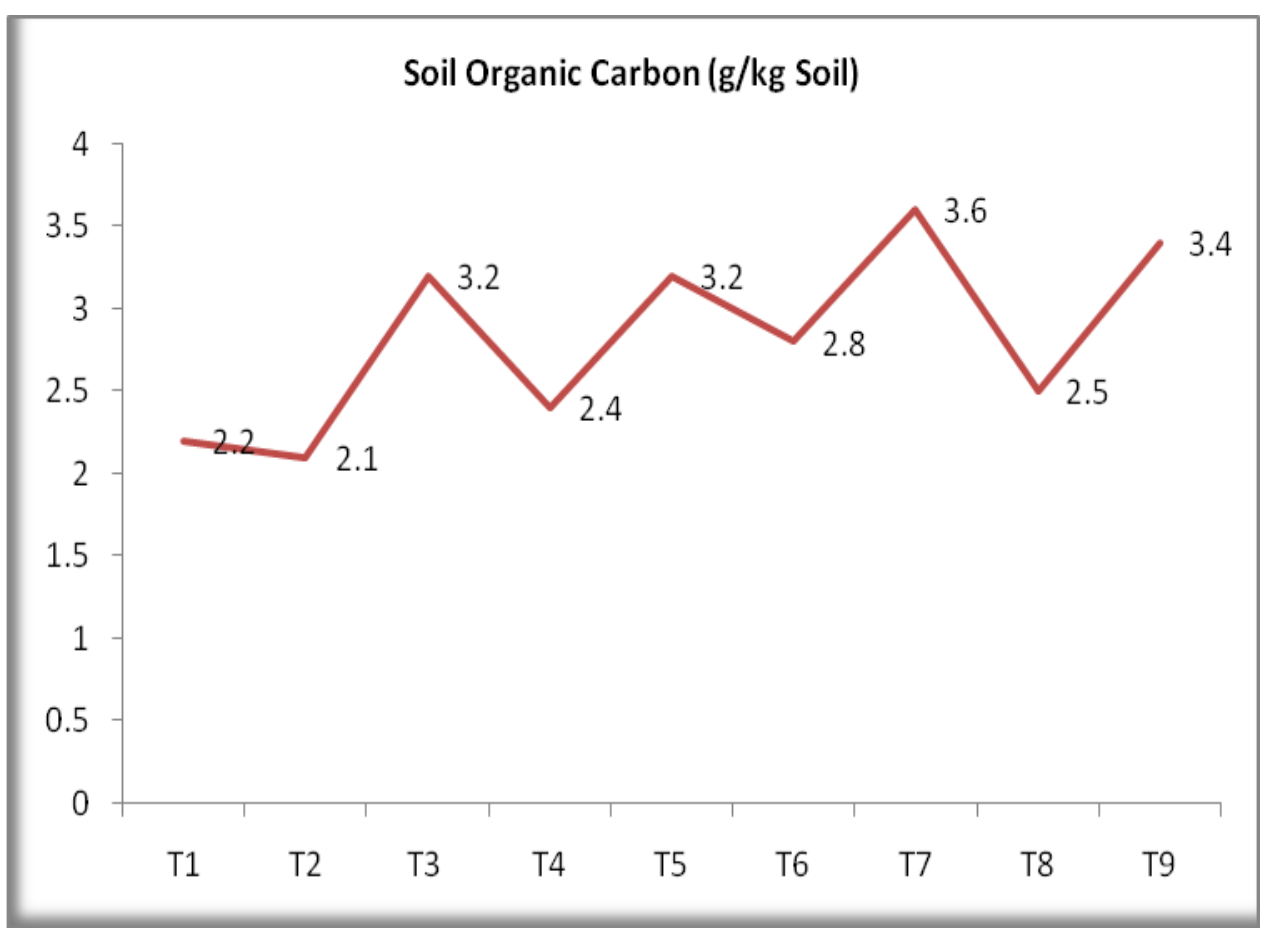


Fig.2 Influence of different levels of NPK, FYM and sulphur on water holding capacity of soil (CD at $5 \% 1.11)$

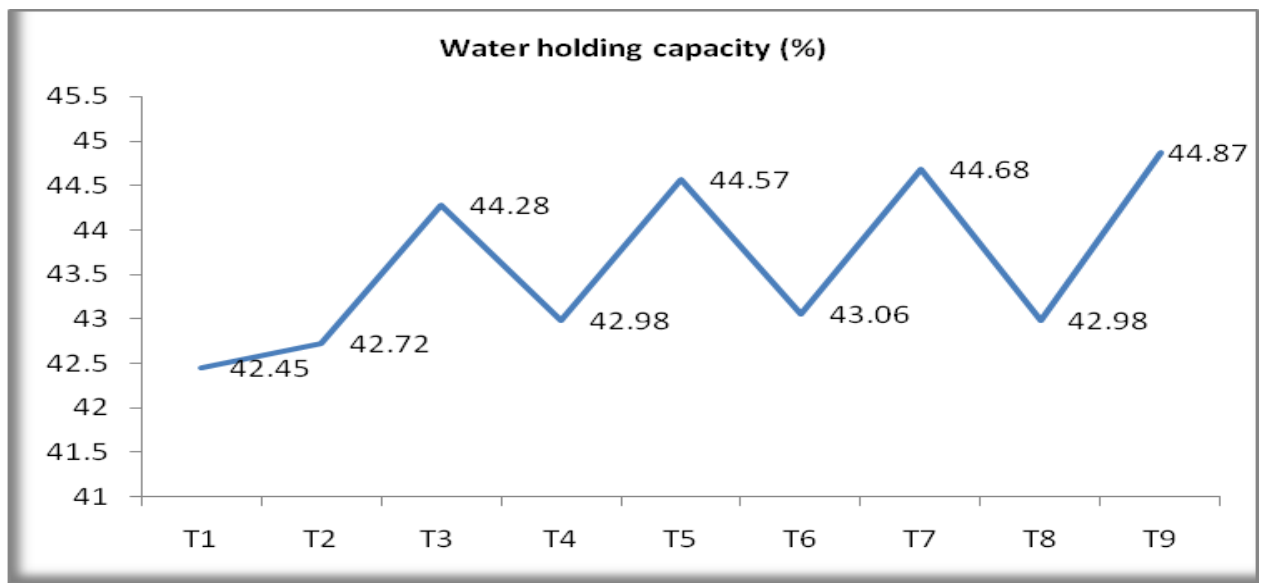

Fig.3 Influence of different levels of NPK, FYM and sulphur on BD, pH and ECe of soil (CD at $5 \% \mathrm{NS}$ in $\mathrm{BD}, \mathrm{pH}$ and $\mathrm{ECe}$ )

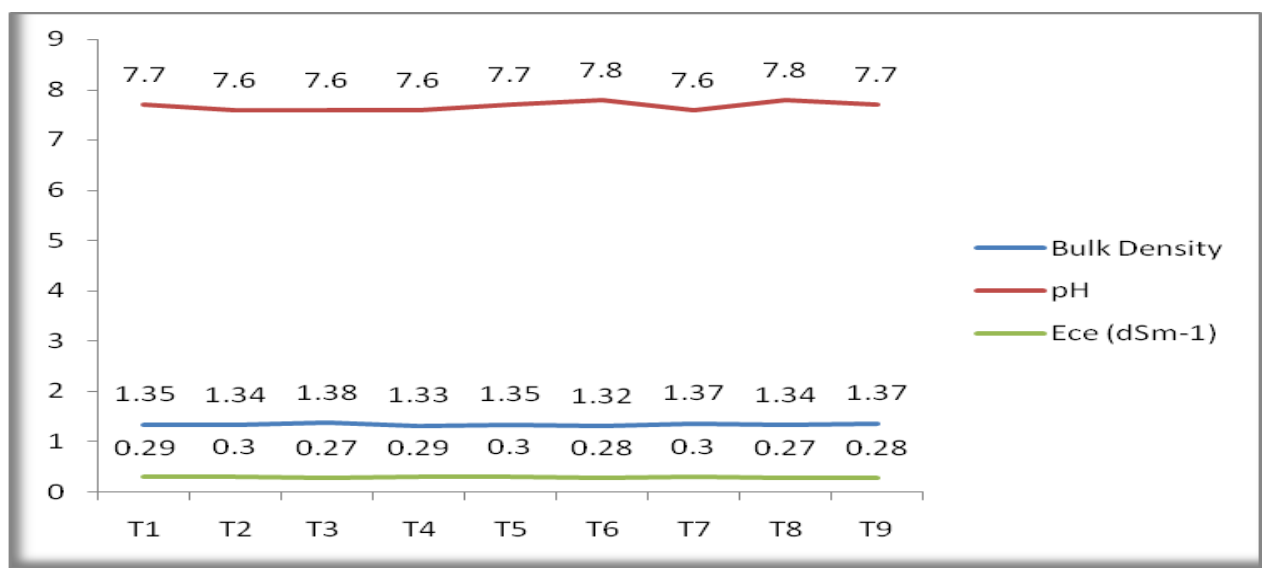

Fig.4 Influence of different levels of NPK, FYM and Sulphur on available N and K in soil (CD at 5\% Available N-12.6, Available K-11.2)

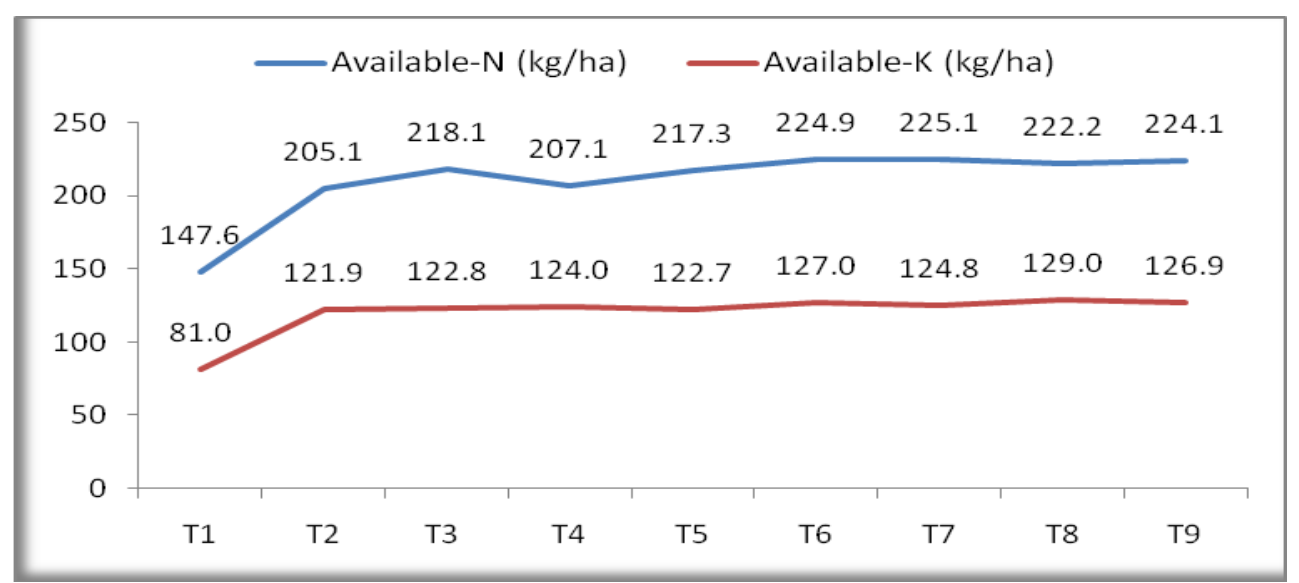


Fig.5 Influence of different levels of NPK, FYM and sulphur on available P and S in soil (CD at 5\% Available P-1.6, Available 0.96)

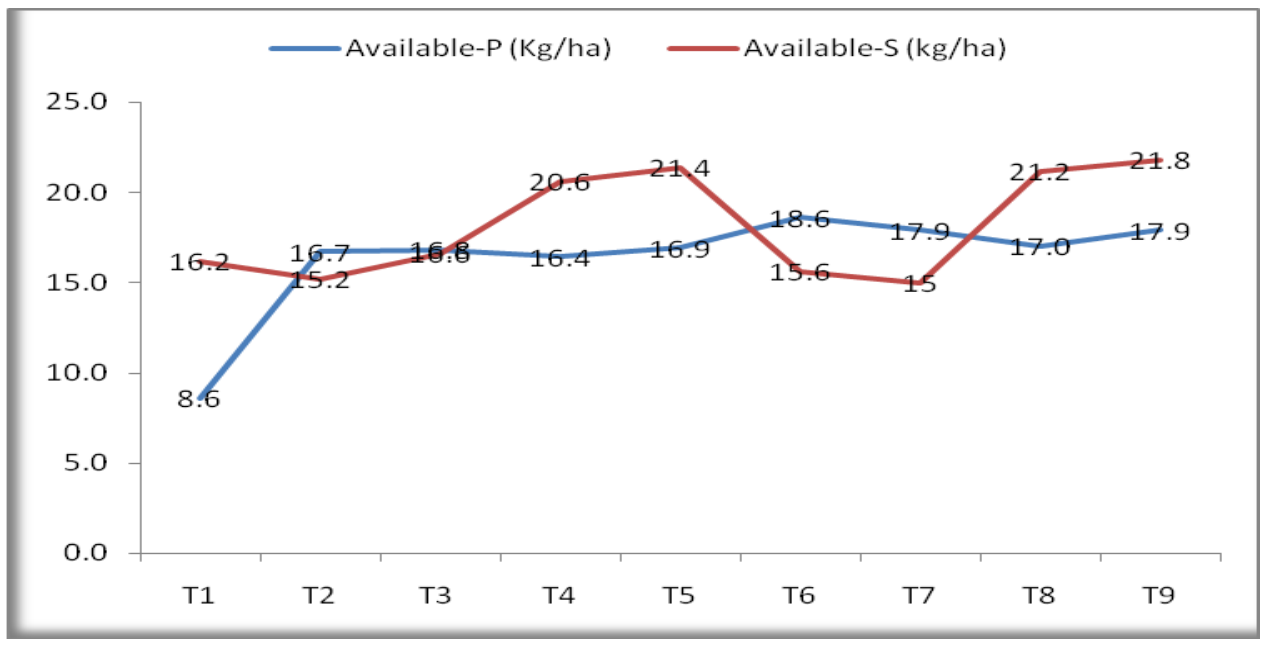

Fig.6 Influence of different levels of NPK, FYM and sulphur on balance N and K in soil

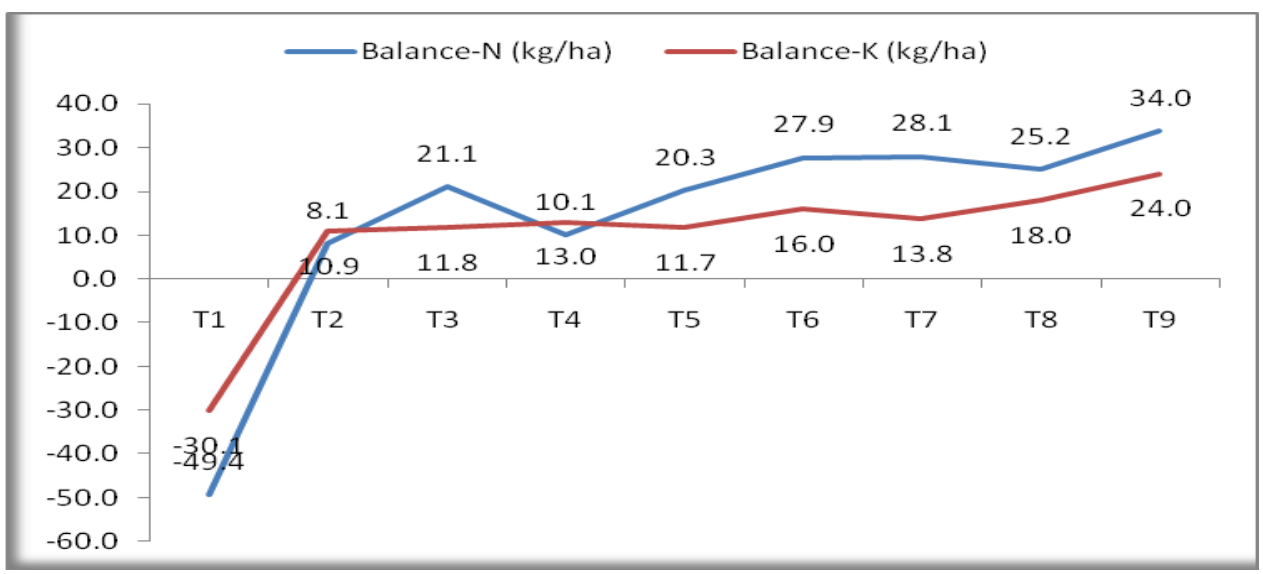

Fig.7 Influence of different levels of NPK, FYM and sulphur on balance P and S in soil

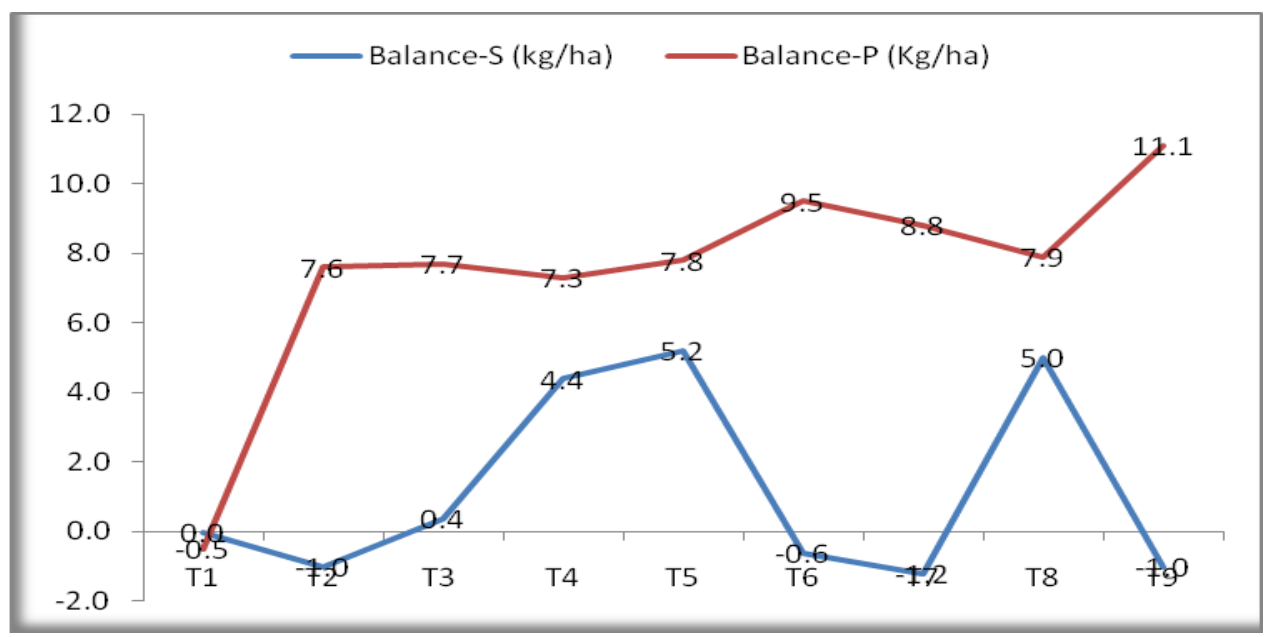




\section{Available nutrients}

\section{Nitrogen}

Available $\mathrm{N}$ increased significantly (Fig. 4) with 75 and $100 \%$ RDF of NPK alone and in conjunction with FYM or sulphur or both. The higher increasing in available $\mathrm{N}$ was recorded in soil with the application of 75 and $100 \%$ RDF of NPK or NPK and sulphur with combined use of FYM over without FYM.

A highest value $225.1 \mathrm{~kg} \mathrm{ha}^{-1}$ of available $\mathrm{N}$ was recorded with the treatment consisting $100 \%$ RDF of NPK conjunction with FYM followed by $224.9 \mathrm{~kg} \mathrm{ha}^{-1}$ with $100 \% \mathrm{RDF}$ of NPK, whereas least $147.6 \mathrm{~kg} \mathrm{ha}^{-1}$ was found with control. Tadesse et al., (2013) and Hemalata et al., (2013) also reported the similar findings.

\section{Phosphorus}

Available $\mathrm{P}$ increased with the increasing level of NPK alone or in combination with FYM or sulphur or both (Fig. 5).

Application of $100 \%$ RDF of NPK recorded the highest $18.6 \mathrm{~kg} \mathrm{ha}^{-1} \mathrm{P}$ content in soil after the harvest of crop followed by $17.9 \%$ with treatments100\% RDF of NPK with FYM alone and combined with $100 \%$ RDF of NPK with both FYM and sulphur and least8.6 kg $\mathrm{ha}^{-1}$ by the control. Corroborative findings also were reported by Tadesse et al., (2013) and Hemalata et al., (2013).

\section{Potassium}

Post-harvest availability (Fig. 3) of K varied from $81.0 \mathrm{~kg} \mathrm{ha}^{-1}$ with control to $129.0 \mathrm{~kg} \mathrm{ha}^{-1}$ with $100 \%$ RDF of NPK combined with sulphur followed by $126.9 \mathrm{~kg} \mathrm{ha}^{-1}$ with treatment $100 \%$ RDF of NPK in combination with FYM and sulphur. Singh (2007) and Hemalata et al., (2013) have been reported the similar results.

\section{Sulphur}

Integration of sulphur with NPK resulted in a maximum residual $S$ availability then other counterparts. As such a highest available $\mathrm{S}$ $21.8 \mathrm{~kg} \mathrm{ha}^{-1}$ was recorded with the application of $100 \%$ RDF of NPK combined with FYM and sulphur followed by $21.4 \mathrm{~kg} \mathrm{ha}^{-1}$ by $75 \%$ RDF of NPK + FYM + sulphur whereas a minimum $16.2 \mathrm{~kg} \mathrm{ha}^{-1}$ was found with the control. It is concluded from the data (Fig. 5) the application of sulphur and FYM improved the available sulphur content in post-harvest soil. Rather and Sharma (2009) and Babar and Dongle (2011) also reported in line with same findings.

\section{Nutrient balance in soil}

There was a positive balance of available nitrogen in the soil (Fig. 6) after the harvest of mustard and moong, the highest build-up of $\mathrm{N}, \mathrm{P}$ and $\mathrm{K}+34.0,+11.1$ and $+24.0 \mathrm{~kg} \mathrm{ha}^{-1}$ respectively, were observed with treatment where FYM and sulphur were combined with $100 \%$ RDF of NPK used as against $-49.4,-0.5$ and $-30.1 \mathrm{~kg} \mathrm{ha}^{-1}$ respectively, found net negative balance with the control treatment. A highest available sulphur balance $+5.2 \mathrm{~kg} \mathrm{ha}^{-1}$ was recorded (Fig. 7) with the treatment where FYM and sulphur both were integrated with $75 \%$ RDF of NPK whereas, a negative S balance was noted in all the treatments where sulphur was not cooperated. Similar results have been reported by Quddus et al., (2012) and Tadesse et al., (2013).

Post-harvest physico-chemical properties like Water holding capacity and organic carbon content were improved as well enhanced availability of $\mathrm{N}, \mathrm{P}, \mathrm{K}$ and $\mathrm{S}$ coupled with net positive nutrient balance are the landmark observations whereas $\mathrm{pH}, \mathrm{ECe}$ and Bulk density of soil were not influenced significantly in mustard-moong crop sequence involving use of FYM and sulphur with 
different levels of NPK. Overall the treatment comprised of $100 \%$ RDF of NPK with FYM and Sulphur proved most effective and promising for sustained crop productivity and better soil health.

\section{References}

Babar, Shilpa and Dongle, J.H. 2011. Soil fertility status as influenced by integrated nutrient management in mustard-cowpea-rice cropping sequence in lateritic soils of Konkan. Asian j. soil Sci., 6:1, 33-38.

Bhattacharyya, R., Chandra, S., Singh, R., Kundu, S., Srivastva, A., and Gupta, $H$. 2007. Long-term farmyardmanure application effects on properties of a silty clay loam soil under irrigated wheat-soybeanrotation. Soil Till. Res. 94, 386-396.

Brar, B.S., Singh, J., Singh, G. And Kaur, G. 2015. Effect of Long Term Application of Inorganic and Organic Fertilizers on Soil Organic carbon and Physical Properties in Maize-Wheat Rotation, Agron. J. 5, 220-238.

Chand, M.,Abrol, I.P. and Bhumbla, D.R. 1977. A comparison of the effect of eight amendments on soil properties and crop growth in highly sodic soils. Ind. J. Agric. Sci. 47, 348- 354.

Gregorich, E., Drury, C., and Baldock, J.A. 2001. Changes in soil carbon under long-term maize in monoculture and legume-based rotation. Can. J. Soil Sci. 81, 21-31.

Hati, K., Swarup, A., Singh, D., Misra, A., and Ghosh, P. 2006. Long-term continuous cropping, fertilisation, and manuring effects on physical properties and organic carbon content of a sandy loam soil. Soil Res. 44, 487-495.

Haynes, R., and Naidu, R. 1998. Influence of lime, fertilizer and manure applications on soil organic matter content and soil physical conditions. A review. Nutr. Cycl. Agroecosys. 51, 123-137.

Hemlatha, S.; Radhika, K.,Maragatham, S., And Katharine, S. 2013. Influence of Long term Fertilization on Soil Fertility- A Review. Research and Reviews: J. Agri. and Allied Sci. 2, 3036.

Lal, R. 2003. Soil erosion and the global carbon budget. Environ. Int. 29, 437450.

Masood, S., Naz, T., Tariq, M., Ahmed, I.,Habibullah, and Iqbal, M. 2014. Effect of short term supply of farmyard manure on maize growth and soil parameters in pot culture. Archives of Agron. And Soil. Sci. 60, 337-347.

Miles, R.J. and Brown, J.R. 2011. The Sanborn Field of Experiment Implications for long term soil organic carbon levels. Agron. J. 103, 268-278.

Ndiaye, B., Molénat, J., Hallaire, V., Gascuel, C., and Hamon, Y. 2007. Effects of agricultural practices on hydraulic properties and water movement in soils in Brittany (France). Soil Till. Res. 93, 251-263.

Parwa, H.P., Yadav, J. and Rakshit, A. 2014. Effect of fertilizer levels, FYM and Bioinoculants on soil properties in Inseptisol of Varanasi, Uttar Pradesh, India 7, 517-525.

Purakayastha, T.J., Rudrappa, L., Singh, D., Swarup, A., andBhadraray, S. 2008. Long-term impact of fertilizers on soil organic carbon pools and sequestration rates in maize-wheat-cowpea cropping system. Geoderma. 144, 370-378.

Quddis, M.H., Rashid, M.A., Hussain, H.M., Naser and Abdin, J. 2012.Integrated Nutrient Management for sustaining soil fertility through chickpea-mungbeant.aman cropping pattern at madaripur region. Bangladesh J. Agril. Res. 37(2), 251-262.

Rather, S. and Sharma, N.L. 2009. Effect of 
integrated nutrient management (INM) in wheat on soil properties and fertility status. Asian Journal of Soil Science. 4: $1,55-57$.

Schuman, G., Janzen, H.,and Herrick, J. 2002. Soil carbon dynamics and potential carbon sequestration byrangelands. Environ. Pollut. 116, 391-396.

Shankar, G., Verma, L. and Singh, R. 2002. Effect of Integrated nutrient management on field and Quality of Indian mustard (Brassica juncea) and properties of Soil. Indian J. Agric. Sci. 72, 551-552.

Sharma, S., and Subehia, S. 2003. Effects of twenty-five years of fertilizer use on maize and wheat yields and quality of an acidic soil in the western Himalayas.
Exp. Agric. 39, 55-64.

Singh, A.K. 2007. Evaluation of soil quality under Integrated Nutrient Management. J. Indian Soc. Soil. Sci. 55, 58-61.

Tadesse, T., Dechassa, N., Bayu, W., and Gebeyenhu, S. 2013. Effects of Farmyard Manure and Inorganic fertilize Application on Soil Physicochemical Properties and Nutrient Balance in Rain-Fed Lowland Rice Ecosystem. American J. Plant Sci. 4, 309-316.

Zhang, M.-K., and Fang, L. 2015. P. Effect of tillage, fertilizer and green manure cropping on soil quality at an abandoned brick making site. Soil Till. Res. 93, 87-93.

\section{How to cite this article:}

Singh Yeshpal, B.S. Duhan and Sharma, N.L. 2017. Physico-Chemical Properties of Soil, Influenced by Different Levels of NPK, FYM and Sulphur in Mustard-Moong Cropping Sequence. Int.J.Curr.Microbiol.App.Sci. 6(12): 4187-4195.

doi: https://doi.org/10.20546/ijcmas.2017.612.481 